Center for American Progress

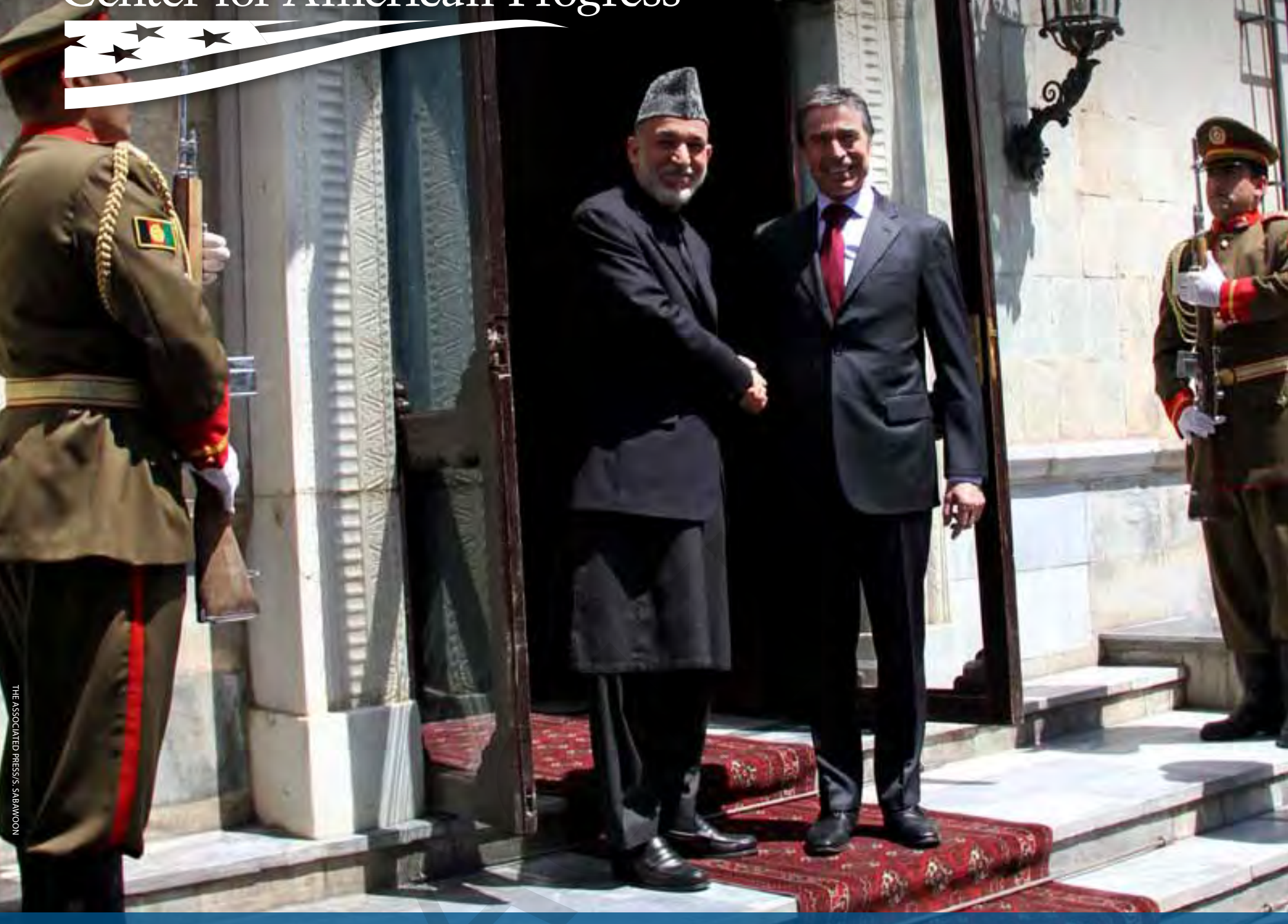

\title{
Afghanistan Transition
}

Elevating the Diplomatic Components of the Transition Strategy at the Chicago NATO Summit and Beyond

Caroline Wadhams, Colin Cookman, and Brian Katulis May 2012 
Center for American Progress

\section{Afghanistan Transition \\ Elevating the Diplomatic Components of the Transition Strategy at the Chicago NATO Summit and Beyond}




\section{Contents}

\section{Introduction and summary}

\section{NATO's transition strategy in Afghanistan requires} more focus on the political dimensions

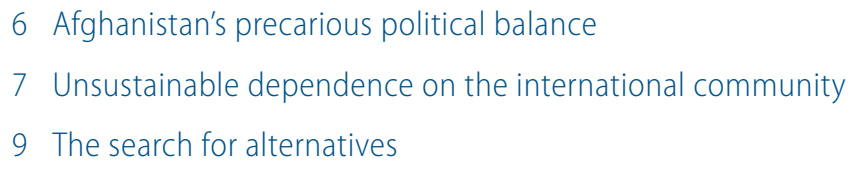

\section{How to bolster diplomacy in pursuit of} an Afghan political settlement
12 Pursuing governance reforms through the political transition process
13 Recommendations for political reforms through the political transition
15 Pursuing a more inclusive political settlement
17 Recommendations for pursuing a more inclusive political settlement process
19 Security transition and mutual commitments
20 Recommendations for reducing the U.S. military footprint and synchronizing military transition with political efforts

\section{Conclusion}

23 About the authors

\section{Acknowledgments}

\section{Endnotes}




\section{Introduction and summary}

Between May 20 and May 21, North Atlantic Treaty Organization heads of state will convene in Chicago to hammer out decisions regarding the handover of responsibility for securing Afghanistan to local forces and the removal of the bulk of foreign troops from Afghanistan by the end of 2014.

For the past 18 months, the Obama administration has rightly pressed a strategy of transition in Afghanistan-reducing the U.S. military presence and encouraging Afghan responsibility. Recognizing that a sustainable transition also requires a political settlement among Afghanistan's diverse factions, the administration has also sought to facilitate an Afghan peace process through outreach to insurgent elements and the Afghan government.

On May 1, 2012, President Barack Obama and Afghan President Hamid Karzai took a step forward with this vision of transition by signing the Strategic Partnership Agreement between the United States and Afghanistan. This agreement outlines a set of mutual commitments between the two countries, with the goal of shifting the long-term relationship toward a more "normalized" one following the withdrawal of the majority of U.S. troops in $2014 .^{1}$

But current transition planning, while correct in its broad strategic strokes, continues to focus too heavily on the military components of the plan and in particular on the Afghan National Security Forces. Missing from the NATO conference's agenda and U.S. government planning efforts is a meaningful discussion of the political dimensions of the transition-how NATO's security transition and international troop drawdown will affect the tenuous power balance that has existed in the country since 2001 among Afghanistan's various factions and how the security transition will sync with the impending political transition, when Afghans go to the polls for the 2014 presidential election.

The NATO conference will focus on the commitments made to the Afghan government as part of the transition strategy, but the Afghan government needs to provide 
commitments in return, or there needs to be a plan for consequences of inaction. The U.S.-Afghanistan Strategic Partnership Agreement includes pledges from the Afghan government in terms of tackling corruption, improving governance, and strengthening financial management. But, as in the past, the agreement does not specify what U.S. commitments are tied to Afghan government performance.

The international community has instead opted to separate these political conversations from the security ones and shift those concerns to a lower-profile conference of international donors taking place in Tokyo in July. Putting off this vital discussion on Afghanistan's political future makes the Chicago summit a missed opportunity, given the degree to which these issues are intrinsically linked to Afghanistan's security.

Politics ultimately drive the Afghan conflict and consequently hold the key to its resolution. The insular nature of the Afghan government is in fact alienating much of its population and contributing to insurgent mobilization-a reality that threatens the Afghan government if a broader political consensus among the Afghan public is not reached.

Indeed, the most recent public Pentagon assessment of the conflict cautions that the insurgency continues to receive support from external sponsors, including Pakistan, and warns that progress in training Afghan soldiers and police is undercut by "widespread corruption, dependence on international aid and mentoring support, and an imbalance of power that favors the executive branch over the legislative and judicial branches." ${ }^{2}$ Despite some successes in disrupting insurgent control of Afghan territory over the past two years, the insurgency's organizational capabilities appear to be resilient, challenging the ability of the Afghan security forces to stem insurgent expansion. ${ }^{3}$

The United States must strike the right balance between providing enduring support and continuing the ongoing transition to Afghan responsibility. While continued support for Afghanistan's stability is an important interest for the United States and its international partners, the withdrawal of U.S. forces as part of the transition to an Afghanistan secured by local forces is essential for both broader U.S. strategic interests and for the development of a more stable political equilibrium within the country.

Large-scale foreign military involvement in Afghanistan distorts the current balance of power within the country and allows Afghan leaders to avoid making difficult but essential political reforms. It also serves as a recruiting tool for Afghan insurgents, who exploit the population's resentment of international forces to 
justify their cause. Other countries in the region remain suspicious of NATO, and in particular U.S. intentions, inviting spoiler behavior.

Moreover, the large financial commitment supporting U.S. and NATO military personnel, coupled with the lack of public accountability mechanisms within the Afghan government, has exacerbated corruption within both the Afghan government and the broader Afghan society—not only undermining the Afghan government's legitimacy but also indirectly funding insurgent activity. ${ }^{4}$

This imbalance and lack of synchronization between the military and political components of transition planning and implementation increases the risk of insecurity in Afghanistan in the medium and long terms. The main thrust of the U.S. and NATO International Security Assistance Force transition continues to be military operations against insurgents, especially in the south and now increasingly in the east, along with the establishment of a large Afghan national army and police force of approximately 352,000 personnel, which will assume responsibility for ongoing conflict as international forces decline in number.

Placing sole responsibility for Afghanistan's future stability on the Afghan National Security Forces without making progress in creating a stronger political consensus among Afghanistan's diverse factions - both armed and unarmed-is a high-risk gamble. While the NATO International Security Assistance Force has met its targets as far as the number of Afghan forces trained, the capacities and loyalties of these forces, in combination with uncertain funding streams, puts their long-term viability in doubt.

The Afghan government will face a serious test in 2014, as President Karzai, under the provisions of the Afghan constitution, transfers power to another democratically elected Afghan leader. Significant work remains to be done by the Afghan government and its sponsors to support efforts to strengthen their political system, including establishing political parties, ensuring the independence of election officials, and establishing a voter registration system or viable alternative in order to avoid a repeat of the highly contentious elections of 2009 and 2010.

As the United States manages the transition and continues the reduction of its military and financial investments in Afghanistan, it retains an interest in both Afghan and regional stability and in preserving the gains and sacrifices of the past 11 years of the Afghan mission, especially for Afghan women and minority groups. Doing so requires committing to a settlement that can accommodate a more sustainable political consensus in Afghanistan. 
With U.S. and NATO troops rightly shifting more quickly to an advising, assistance, and mentoring role and away from combat operations throughout the next year, U.S. policymakers must reorient their strategic focus toward the political and diplomatic processes best suited to addressing the crux of Afghanistan's problems: the political dimensions of the conflict that drive insurgent recruitment and opposition to the government.

President Obama hit the right notes in the Strategic Partnership Agreement and during his speech at Bagram Air Base earlier this month when he coupled a commitment to a handover of responsibility to Afghan leaders with calls for a negotiated peace settlement and for Afghan government reforms. In order to make good on these goals, we have outlined in this paper a clear set of recommendations for U.S. officials and NATO leaders to follow:

- Begin serious preparations for the 2014 Afghan presidential elections now, including support for free and fair elections, political outreach to different political parties and leaders, and the establishment of governmental checks and balances outside of the country's executive branch.

- Facilitate an inclusive and transparent Afghan peace negotiations process among the various factions, in concert with regional diplomatic efforts.

- Clarify expectations for the Afghan government through a set of conditions and incentives tied to Afghan government performance.

- Align military and political efforts in support of a credible political transition and an inclusive settlement process, while pursuing a steady drawdown of U.S. forces beyond the fall of 2012 .

A transition to Afghan ownership and the drawdown of foreign forces is the right approach for the long-term interests of Afghanistan, the region, and the United States and its NATO partners. But for this approach to be successful and sustainable, there must be a clear recognition by all involved that a security transition is inextricably linked to a political transition. Clearly, more work needs to be done to prioritize and carry out the steps necessary for a durable resolution to the political issues at the core of the conflict.

\section{U.S. policymakers}

must reorient their

strategic focus

toward the political

and diplomatic

processes best

suited to addressing

the crux of

Afghanistan's

problems: the

political dimensions

of the conflict. 


\section{NATO's transition strategy in Afghanistan requires more focus on the political dimensions}

As the United States continues to degrade the operational capability of Al Qaeda and its affiliates in Afghanistan and the immediate region, it is also facing a host of competing strategic priorities in Asia, the greater Middle East, and at home. As such, we are now realigning our military and financial investments in Afghanistan to more sustainable levels and reorienting to other strategic priorities.

Since 2010 the United States and its NATO allies have carried out a process of gradual security transition whereby increasing numbers of Afghan military and police forces gradually assume "lead security responsibility" across the country, culminating with a full transfer of those responsibilities and the withdrawal of most international military forces by the end of 2014 . The process has already begun in two tranches of territories, and with the drawdown of U.S. and other foreign troops from their peak numbers in 2010 and 2011. ${ }^{5}$ President Karzai announced a third round of transition, reaching all 34 provincial capitals and more than 230 districts to begin the week before the Chicago conference. ${ }^{6}$

U.S. and NATO officials have discussed security dynamics in Afghanistan separate from the underpinning Afghan political system, and have overestimated the Afghan national security forces' ability to control the crises facing the state in the medium and long terms. Even if training targets for local security forces are met and the insurgency is weakened through continued joint operations, the Afghan military risks emerging as a security force without a state.

The fact is that political support for the Afghan government is fragile, as it has generated growing opposition from a diverse set of rivals and lacks the means to mobilize internal political and financial support. The Afghan government as currently established will be unable to sustain itself against domestic and regional challengers without large-scale external aid for decades to come, even as its primary sources of power and legitimacy — foreign financial flows and military forces-are in necessary decline. 
The upcoming drawdown of international forces and the Afghan presidential election in 2014 have the potential to seriously upset the tenuous power balance that has existed in Afghanistan since 2001, with unpredictably disruptive effects for Afghanistan, the region, and indirectly for U.S. security.

This section outlines the multiple crises facing the Afghan government that must be addressed in a successful transition strategy. Making open-ended commitments in an effort to perpetuate the status quo or escalating conflict with insurgent sponsors both have the potential to be equally damaging to U.S. interests and are not viable alternatives to transition. But the medium- to long-term viability of the current plan remains in doubt due to insufficient emphasis on the political situation, which demands greater prioritization within the overall strategy.

\section{Afghanistan's precarious political balance}

There is a real risk of fracture in the wake of a reduction in direct U.S. military intervention in support of Afghanistan's current ruling coalition. Should factions inside and outside the Afghan government decide to take up arms against each other, they would have a ready supply of armed professionals from which to draw, including both regular police and army forces and a proliferation of irregular police and militia forces, many currently supported by NATO trainers. The Afghan National Security Forces - the central component of NATO's transition plan-risks contributing to greater instability in the event of a political breakdown.

President Karzai's government has managed to maintain relative control of the country thus far thanks to the support of the international community and his successful co-optation of various powerbrokers and potential rivals through the manipulation of the formal and informal powers of his office. But the executive branch's disconnect from - and in many cases active resistance toward-the emergence of other centers of powers has left it poorly positioned to mobilize or sustain domestic coalitions of support. The government lacks sustainability, sufficient checks and balances, and popular legitimacy.

Under the current system President Karzai directly or indirectly appoints thousands of positions countrywide, from election officials to governors to district police chiefs - many of whom pay exorbitant "rent" for their positions. Decisions concerning funding or the provision of services are generally made in the capital city of Kabul. There are few, if any, avenues for Afghans to redress wrongs or to influence government decision making. 
Further, formal institutions, including the parliament, the judiciary, and local government bodies, are weak and have little real authority and ill-defined responsibilities. The strong executive branch enables abuse and pervasive impunity, which are perceived as protected and enabled by NATO and the International Security Assistance Force, engendering further disillusionment with the Afghan government and fueling insurgent recruitment. ${ }^{7}$ Given the overcentralization of the system, its international backers remain one of the few constituencies capable of holding the Afghan government accountable - and pressing it to change its practices in this regard.

The political transition scheduled to occur with the constitutionally mandated presidential elections in 2014 has the potential to exacerbate these tensions, as interests both within and outside the Karzai regime compete over who will succeed him as president. To the extent that this competition takes place within the confines of a political system - however loose and informal that may be in Afghanistan - it can contribute to the country's stabilization, if interest groups view it as fair and legitimate and choose to compete peacefully rather than through armed conflict.

Unfortunately, there remains a risk of repeating the highly flawed elections of 2009 and 2010. The problems that contributed to the previous election failures remain, including insecurity, especially in the south and east of the country where the insurgency is strongest; a flawed electoral system that disempowers most voters and marginalizes political parties; the absence of a credible voter registry; and the limited independence and authority of election officials.

The winner-take-all nature of the Afghan presidency and its control over many of the instruments of electoral authority increase the risks of a highly contested election and discredited outcome. The current system's ability to manage a real transition of presidential power has yet to be tested.

\section{Unsustainable dependence on the international community}

The Afghan government has few licit domestic sources of wealth with which to maintain or consolidate its control. It largely cannot provide services, maintain security, and co-opt potential spoilers on its own. And unlike most strong executives, who view their security services as an essential asset for wielding control, President Karzai largely perceives the Afghan National Security Forces as a U.S. and NATO force, rather than one of his own. Without the international community compensating for its deficiencies, the current Afghan government and political framework lacks 
sufficient popular legitimacy and risks breakdown - being too weak to consolidate power over its rivals and too insular to effectively negotiate their cooptation.

Despite Karzai's public criticisms of the international community and his efforts to assert Afghan sovereignty in negotiations over the terms of a U.S.-Afghan strategic partnership agreement, his primary concern has been to consolidate control over external assistance, not end it. Karzai has sought explicit commitments from the United States and NATO specifying how much financial assistance they will provide to Afghanistan in the long term. ${ }^{8}$ The security bill is only the largest part of a budget still principally funded and managed by the international community. Even with agreement earlier this month on a strategic partnership, U.S. officials have deferred decisions on continued security assistance levels until the Chicago summit and on nonsecurity aid until the donors' conference in Tokyo later this summer, although it is unclear whether this latter session will set specific funding pledges.

Then there are the Afghan national security forces, which despite increased numbers are unlikely to achieve sufficient independence from foreign troops while also establishing the capability to eliminate insurgent challengers in the near term. The performance of the many different overlapping Afghan security agencies and services vary significantly, but the bulk of Afghan forces continue to be reliant on the international community for logistics, intelligence, operational guidance, and airpower. Indeed, the most recent public Pentagon assessment of Afghan National Army battalions and headquarters finds only 15 units (out of 219) judged to be of "independent" capability - and even this definition still allows for dependence on ISAF for "combat support and combat enablers." "What's more, the lack of trust between U.S. and Afghan forces in the wake of increasing insider (so-called "green on blue") attacks on NATO mentors has only made implementation of the training and support mission that much more difficult. ${ }^{10}$

In the event that aid is eventually cut off without a corresponding plan for conflict settlement and demobilization, it risks the fragmentation of the Afghan security forces, which includes both uniformed personnel and irregular forces such as the Afghan Local Police, whose political loyalties and cohesion as a national force have been underanalyzed. While NATO has made a real effort to increase the diversity of the Afghan National Security Forces with outreach to southern Pashtuns, the officer corps remains heavily weighted towards non-Pashtun ethnic groups and former Northern Alliance figures. ${ }^{11}$
Without the

international

community

compensating for

its deficiencies, the

current Afghan

government

and political

framework lacks

sufficient popular

legitimacy and

risks breakdown-

being too weak

to consolidate

power over its

rivals and too

insular to effectively

negotiate their

cooptation. 
The cost of maintaining the Afghan security forces, while far less than fielding American troops, remains outside the financial reach of the Afghan government for the foreseeable future, even when accounting for the completion of large-scale capital investments in arms and material that are expected to reduce funding costs from their peak levels in the 2010-2012 period. Projected annual security force funding costs between $\$ 4$ billion and $\$ 5$ billion-down from more than $\$ 12$ billion in 2012 - will likely require a reduction in force size to around 230,000 police officers and soldiers, a plan to which some Afghan defense officials have publicly objected. ${ }^{12}$

Total Afghan government revenues were only $\$ 1.8$ billion in 2011, and World Bank projections through the year 2022 estimate security spending costs will still be equivalent to as much as 17.5 percent of Afghanistan's gross domestic product-equal to the projected domestic revenues-leaving little room for the government to pursue nonsecurity spending. ${ }^{13}$

Maintaining these financial commitments to the government and security forces indefinitely will be extremely difficult for the United States and its international allies, who face multiple competing priorities for their assistance and attention. A strategy that hinges on such commitments for decades to come poses high risks for both U.S. and Afghan interests.

\section{The search for alternatives}

While risks exist in the current transition strategy, doubling down military efforts as a substitute for the weaknesses of the Afghan government is not a viable course. An indefinite commitment of troop levels and financial assistance with no timelines or expectations from the Afghan government will not advance U.S. security interests or a sustainable peace in Afghanistan. In fact, large-scale aid delivered to a government that lacks credible public accountability mechanisms and without clear conditions and oversight on its use risks further distorting Afghan leaders' political calculations about the necessity for compromise with rivals or assumptions of responsibility for the country's future. Likewise, messages of uncritical support for the Afghan government provide little incentive for leaders currently within government to take responsibility for difficult concessions and reforms.

Another option-escalating conflict with Pakistan in order to directly combat insurgents' external base of support—carries equal or greater risk for U.S. interests. As has been well documented, Taliban and Haqqani network sanctuaries in

\section{An indefinite}

commitment of

troop levels and

financial assistance

with no timelines

or expectations

from the Afghan

government will

not advance U.S.

security interests or

a sustainable peace

in Afghanistan. 
Pakistan provide the insurgency with a base of support that poses serious challenges to current coalition efforts to defeat opponents of the Afghan government. Pakistan's continued support for Taliban proxies and unilateral U.S. military and intelligence action within Pakistani territory have exacerbated bilateral tensions. In addition, Pakistan has failed to deal effectively with growing concerns about the threats posed by terrorist networks that operate within Pakistan. As a result, U.S.Pakistan relations have sharply deteriorated over the past year. ${ }^{14}$

Escalating conflict with Pakistan over the outcome in Afghanistan carries serious risks for U.S. forces serving in Afghanistan and to the regional security balance-with still uncertain impacts on the outcome in Afghanistan, given broader strategic challenges. Further, it would threaten to fully sever the multiple avenues of incomplete but real cooperation that Pakistan and the United States currently maintain, including counterterrorism and intelligence operations targeting $\mathrm{Al}$ Qaeda, nuclear security, and nonmilitary assistance efforts to stabilize Pakistan's economy and support the continuity and consolidation of democratic politics within Pakistan. Recent trilateral talks between the United States, Afghanistan, and Pakistan have affirmed a mutual commitment for the facilitation of talks that could include the Taliban. ${ }^{15}$ In addition, Pakistani leaders have shown increasing willingness to speak publicly in support of broad Afghan reconciliation. Although Pakistani political and military leaders appear internally divided over their own interests in U.S.-Pakistan cooperation, the government is not monolithically opposed in this regard, and shutting off the relationship risks a breakdown of this channel and would further stall intra-Afghan settlement talks.

Continuing to seek cooperation with Pakistan at this time does not remove the option of ending that cooperation in the future should Islamabad prove irrevocably opposed to participating constructively in talks toward a more sustainable political settlement in Afghanistan. But given the costs to America's significant shared interests with Pakistan and the marginal strategic benefit of an escalated conflict with Pakistan, this option should be pursued only as a last resort.

Undeniably, risks are associated with every policy currently available to the United States in Afghanistan. But the uncertainty of the current trajectory requires U.S. and NATO policymakers to reprioritize diplomatic efforts toward political reform and a political settlement in an effort to mitigate the effects of reduced military engagement and financial assistance. The remainder of this paper outlines some of the key components of such a strategy. 


\section{How to bolster diplomacy in pursuit of an Afghan political settlement}

The Obama administration has spoken consistently about the need for a political resolution to end the Afghan conflict. More than a year ago, Secretary of State Hillary Clinton expressed explicit support for a reconciliation process with Afghan insurgents, acknowledging that a successful reconciliation would create a more sustainable transition to Afghan control. ${ }^{16}$ But despite an increase in nonmilitary support in Afghanistan, the Obama administration's planning for this process remains underdeveloped and unsynchronized with its military campaign to weaken the insurgency and its parallel efforts to strengthen the Afghan government.

Achieving a political settlement is an undeniably daunting challenge for the Obama administration and is ultimately dependent on Afghan leadership and willingness to compromise. Given Afghanistan's fractured society and the existence of powerful individuals both in and out of government structures - who maintain linkages with armed groups and revenue streams within Afghanistan and/or with foreign governments - striking a political deal with all parties may prove out of reach.

Achieving even a partial settlement, however, will require a renewed focus by the Afghan government and the United States and its allies on political reforms that address the unaccountability and overcentralization of the existing system, and more inclusive outreach to insurgent groups and factions currently marginalized from the governing coalition.

The two pathways for pursuing these objectives are through the presidential elections in 2014 and the simultaneous negotiation process with insurgents and other Afghan factions. These two tracks in fact may be overlapping and reinforcing. A legitimate election process, for example, may strengthen the Afghan state in negotiations with insurgents, while those negotiations may in turn provide opportunities for some insurgents to join the formal political process. A political settlement will also demand greater clarity on the nature of U.S. commitments to and expectations from Afghanistan. 
Moving beyond the unstable status quo to achieve a more sustainable political consensus in Afghanistan requires greater access to participation in the political system, more opportunities for power-sharing, and more mechanisms for Afghans to hold their leaders accountable. Currently, institutional checks in the system, including the parliament, the judiciary, and local government bodies, are weak due to lack of authority, undefined responsibilities, and financial dependence on President Karzai's office.

Maintaining support for the state system will ultimately require reforms that increase these institutions' powers and offer the chance to accommodate the interests of more actors, including both the unarmed domestic opposition and insurgent parties willing to enter into a political process.

While negotiations over these checks and balances and expanded participation in the system will likely be a decades-long process, the upcoming 2014 Afghan presidential election offers a critical opportunity for creating greater buy-in from Afghan factions, mobilizing political parties, generating dialogue among Afghans about the future of their country, and strengthening the legitimacy of the Afghan government-all of which will be contingent on the elections being perceived as free and fair.

Term limits as outlined in the constitution require that President Karzai step down from the executive role he has held since the earliest days of the interim government in 2001. Some Afghan political actors-mostly veterans of the now-much-divided former Northern Alliance, the anti-Taliban coalition of the 1990s - have already begun tentative mobilization and coalition-building efforts readying for this contest. ${ }^{17}$ Despite verbal pledges to abide by the constitutional limits, President Karzai-who has repeatedly opposed the development of a political party system - does not appear to have settled on a successor, exacerbating uncertainty about whether he will step down and about the openness of the election process. Consequently, U.S. government preparations for the elections must begin now.

Allegations of widespread fraud in the past round of presidential elections in 2009 and Karzai's determination to circumvent existing election bodies during the 2010 parliamentary elections by setting up a parallel court to rehear complaints marred both elections and eroded the government's legitimacy domestically and abroad. ${ }^{18}$ 
As in many other Afghan government institutions, the autonomy of the Independent Election Commission and the Electoral Complaints Commission is compromised by the fact that commission members are directly appointed by the president, with few checks or oversight of the process from parliament or other government bodies. ${ }^{19}$

While President Karzai has recently voiced strong opposition to international interference in the presidential elections, it is imperative that the United States and other international donors, including the United Nations, commit to supporting a free and transparent election to determine the next Afghan president and to holding the Afghan government accountable for its pledges in this regard. This does not mean picking Karzai's successor, but it does mean conditioning U.S. financial support for the election and additional programs on a credible, transparent process in which President Karzai transfers power to another democratically elected Afghan leader. The United States should not support political institutions and processes that lack sufficient legitimacy, transparency, and fairness.

\section{Recommendations for political reforms through the political}

\section{transition}

We urge the U.S. government to undertake the following actions leading up to the Afghan presidential elections in 2014:

\section{Support for free and fair elections}

U.S. officials must clearly signal the importance of a credible and acceptable election process and must clarify that the election-related commitments made by Afghanistan in the Strategic Partnership Agreement are more than rhetoric. Accordingly, American officials must continue to communicate to Afghan officials in no uncertain terms that the United States fully expects President Karzai to abide by constitutional term limits and step down from office in 2014. At the Chicago summit and at the Tokyo donors conference, the United States and other countries will make commitments to Afghanistan's long-term development and institution building. Holding credible presidential and parliamentary elections in 2014 and 2015 should be agreed upon as a clear baseline in return for any long-term U.S. assistance.

U.S. officials must

clearly signal the

importance of

a credible and

acceptable election

process and must

clarify that the

election-related

\section{commitments}

made by

Afghanistan in

the Strategic

Partnership

Agreement are

more than rhetoric. 


\section{Support electoral reform}

U.S. officials should hold the Afghan government accountable for its implementation of electoral reforms and for the degree to which it allows space for civil society, reformers in the Afghan government, and advocates in parliament who are working to improve the electoral process and are addressing the flaws that undermined the previous elections in 2009 and 2010. These reforms include:

- Establishing a credible national voter registry or an effective substitute;

- Creating a clear electoral calendar for the presidential, provincial council, and parliamentary elections;

- Enhancing the autonomy of the electoral bodies such as the Independent Election Commission and the Electoral Complaints Commission;

- Reforming the single nontransferable voting system before the next round of parliamentary elections, which has hamstrung the formation of political parties;

- Supporting civic education for the Afghan population.

\section{Promote increased checks and balances outside of the executive branch}

The main thrust of U.S. diplomatic efforts should be to assist Afghans in building a solid and inclusive political foundation. U.S. officials must be cautious about stepping into questions of intra-Afghan constitutional reform debates, but leading up to and beyond the 2014 election, the United States should assist with the goal of supporting checks in the system such as the parliament, the judiciary, and local government bodies. The support should include funding and training as well as finding opportunities for these institutions to provide an oversight role. Pilot programs devolving budgeting authority to elected provincial bodies should be further incentivized, and parliamentary and local oversight must be made a condition for support to government-run aid programs.

\section{Conduct political outreach and support to opposition}

While the U.S. government should not pick a leader or political party to succeed President Karzai, the U.S. embassy should meet with a diverse set of Afghan political parties and leaders in the lead up to the election. A number of parties have already emerged including Truth \& Justice, Hope \& Change, and the National Coalition for Afghanistan. Such efforts would signal support for an open electoral 
process and genuine competition. In addition the United States should continue to provide funding for training political parties.

\section{Pursuing a more inclusive political settlement}

In his speech at Bagram Air Base in early May, President Obama reasserted his administration's commitment to reconciliation, stating that the Taliban could be part of a political solution if they agreed to meet the three redlines of the U.S. government: sever ties with $\mathrm{Al}$ Qaeda, renounce violence, and adhere to the Afghan constitution. Several obstacles, however, stand in the way of the pursuit of such a settlement.

As of this writing, efforts by the United States and the Afghan government to initiate reconciliation talks with the Taliban insurgency appear to be stalled. The Taliban leadership - mindful of internal dissension over talks with the government-have repeatedly disavowed interest in holding discussions with President Karzai. Following a deadlock over the terms of a prisoner exchange, the Taliban leadership has suspended initial talks with the United States, which Qatar mediated. ${ }^{20}$ Resistance to concessions is mutual, as Afghan leaders both inside and outside government have rejected accommodation with their opponents. ${ }^{21}$

At present Afghanistan lacks a clear forum to conduct a serious political settlement with insurgents and other unarmed factions. The Karzai-appointed High Peace Council's ability to negotiate for the government is complicated by its fractious membership and uncertain mandate. Following the assassination of its former Chairman Burhanuddin Rabbani, the chairmanship of the council has now passed to his son, Salahuddin Rabbani, who is also attempting to consolidate control over the remnants of his father's Jamiat-e-Islami party. ${ }^{22}$

Efforts to co-opt insurgent support through financial incentive programs such as the Afghan Peace and Reintegration Program have only drawn in a small portion of Taliban fighters to date, mostly Tajiks from the north and west. ${ }^{23}$ Given the centralization of power within the presidency, neither the High Peace Council nor the provincial-level Afghan Peace and Reintegration Program councils appear to be empowered to seriously engage in local-level grievance resolution or local political agreements that might involve government concessions. It is not yet clear what the Afghan government is discussing with Taliban representatives, or if there is any meaningful discussion at all. 
The Obama administration and U.S. Congress have also found it difficult to push the Afghan government to reform or make concessions, often characterizing reconciliation as insurgents acquiesing to the status quo rather than a process of give and take.

Despite these impediments, reconciliation may yet be possible. All Afghan factions lived through the devastation of 30 years of civil war. Pakistan, a primary benefactor of the Taliban insurgency, is suffering from economic, political, and security crises and would be threatened by increased violence across its border. While Pakistani leaders want to maintain influence in Afghanistan's future settlement, they have expressed support for an internal settlement in Afghanistan and do not appear to want an exclusively Taliban-controlled government in Afghanistan. ${ }^{24}$ In their suspension of talks, Taliban statements indicated concern over the U.S. government's ability to deliver on its own proposed confidencebuilding measures — not an outright objection to talks of any kind. ${ }^{25}$

U.S. diplomats, led by Ambassador Marc Grossman, have publicly emphasized that their goal in initial Taliban outreach talks has been to press for an intraAfghan negotiation. ${ }^{26}$ Despite setbacks, this effort must continue and be bolstered using American leverage with the Afghan government, Taliban representatives, broader Afghan civil society and domestic opposition, and neighboring countries to find a more durable political settlement.

Without a doubt, a successful political negotiation process will be very difficult to achieve given the divisions within the insurgency and the broader Afghan population. But the pursuit of such a settlement provides benefits by clarifying the objectives and potential concessions of the parties, testing their intentions, and clarifying who can deliver. Further, a political settlement process may enable reform of the current system through greater inclusion of marginalized groups. The process may also empower the pragmatic elements of the Taliban while marginalizing the extremist ideologues, as well as sow dissent and confusion within the ranks of the insurgency-if the U.S. and Afghan government offer some confidence-building measures to strengthen their position within a divided movement. News outlets have already reported that recent negotiations between the Taliban and the United States have undermined morale among insurgents. ${ }^{27}$ 


\section{Recommendations for pursuing a more inclusive political settlement process}

We urge the Afghan and U.S. governments and their NATO partners to undertake the following actions to pursue a more inclusive political settlement process:

\section{Identify a negotiations forum that allows for more stakeholders}

The current Afghan government is a legitimate stakeholder in any Afghan settlement process. But its attempts to lead an inclusive negotiations process through the High Peace Council have foundered. The United States and its international allies must take a more active role in identifying a negotiating forum with the Afghan government in which the broad array of Afghan interest groups, including women, northern groups, civil society leaders, non-Taliban Pashtun communities, and the Taliban itself can have their concerns heard.

Without greater transparency in this process, participants are likely to grow suspicious that each group is forging its own separate peace with other players in the conflict. This not only weakens the prospects for any consensus agreement but also the ability of leaders to negotiate on behalf of supporters who are still divided over the benefit of talks.

The United Nations, Qatar, Turkey or Saudi Arabia all offer potential forums but care must be taken by the U.S. and Afghan governments in selecting a neutral setting for facilitating talks to which all Afghan actors —including women's groups-have access and representation.

\section{Consult regional actors in settlement talks}

Regional involvement will be necessary to achieve a settlement that addresses the interests of neighboring countries and offers a framework for the protection of sovereignty for both Afghanistan and its neighbors. The appointment of a neutral international coordinator under the auspices of the United Nations could facilitate dialogue among regional countries such as Iran, whose relations with the United States are strained. As America draws down its military presence, a neutral mediator through the United Nations might be beneficial for building regional buy in and ownership, and can also enable the United States to reduce its centrality to the 
peace process-although clear U.S. signals of commitment to this process will be necessary for others to see it as a forum worth participating in.

\section{Continue to engage Pakistan in settlement talks}

Breaking out of a counterproductive cycle of mutual suspicion and recrimination between the United States and Pakistan requires continued engagement with both civilian and military leaders. In this regard, the resumption of U.S.-Pakistan -Afghanistan trilateral talks, high-profile U.S.-Pakistan bilateral meetings in April, and President Asif Ali Zardari's attendance at the Chicago summit, were all welcome signs, even if clear breakthroughs in relations have yet to be reached. All sides have affirmed their interest in a peaceful and stable Afghanistan, but greater dialogue is necessary to clearly determine which actors are likely to engage in negotiations and which remain irreconcilable. In addition, it remains to be seen how the United States and Pakistan can work in concert to support an Afghan peace process that respects all sides' interests and expectations. The United States should still be prepared to put forth a more explicit set of positive and negative inducements to get Pakistan to act against those militant parties unwilling to negotiate.

More broadly, the United States and Pakistan need to redouble their efforts to enhance strategic coordination on a wide range of issues including counterterrorism, military cooperation, and regional economic integration. This will require the United States to shift even more attention towards the challenges and opportunities in Pakistan. Pakistan is currently undergoing an important debate about how to reform its own government and how it could play a more constructive role in the region, as seen in the recent steps to build economic and trade ties with its neighbors. As difficult as the past year has been in U.S.-Pakistan ties, Pakistan remains a key player in the region, and the United States needs to remain engaged.

\section{Focus talks on identifying common, competing, and negotiable interests}

Building confidence in a political settlement process requires clear signals from all sides that they are willing and able to make concessions, and that commitments from any one actor will not be one-sided but rather matched by others. The details and initial negotiating postures of the various parties may change, but at their core, these concessions are likely to revolve around: 
- Recognition and acceptance of the current constitutional framework

- Recognition of portions of insurgency as a legitimate political movement

- Guarantees for Pakistan of its territorial sovereignty and security

- Guarantees of some level of federalism to protect the northern opposition's local independence from Kabul

- Clear renunciation of Al Qaeda by the Taliban

Ultimately, each side's leadership must demonstrate to their constituencies that they can advance their interests more effectively through negotiations rather than violence. Early confidence-building measures will therefore be required to move this process forward. At this stage, the potential of these steps to unlock a more substantial series of concessions - potentially including local or regional de-escalation of insurgent and coalition military operations-outweighs the relatively minor strategic risks to the United States of an individual prisoner transfer or permission of safe passage for negotiating to take place.

These concessions must drive toward a Taliban commitment to enter into serious dialogue with the Karzai administration and other Afghan actors about the future structure of the Afghan political system. The establishment of a Taliban office in Qatar can be an incremental step in this regard, but international legitimation of the Taliban through their leaders' further removal from the U.N. terror blacklist should be incumbent on their participation in a durable intra-Afghan settlement process and the clear renunciation of Al Qaeda.

\section{Security transition and mutual commitments}

The recent Strategic Partnership Agreement is an important step toward clarifying the details of U.S. commitments in Afghanistan beyond 2014. But such commitments must be reciprocal. One-way messages of support for the Afghan government provide little incentive to leaders currently in government to take responsibility for difficult concessions or reforms. Additionally, without such concessions most insurgent rivals are unlikely to consider joining a system that provides them with few institutional bases of power in which to participate, short of the presidency.

Despite efforts to separate the issues, the Afghan government's willingness to undertake political reforms and join in an inclusive political settlement, along with the international community's support for Afghanistan's continued security, are in fact intrinsically linked. U.S. officials must clearly convey that American
Ultimately, each

side's leadership

must demonstrate

to their

constituencies that

they can advance

their interests more

effectively through

negotiations rather

than violence. 
commitments - both in terms of security assistance and financial aid — to Afghanistan's stability are not unconditional, and that the perpetuation of a narrow regime unwilling to share power with rivals is not an overriding interest to which the United States will contribute indefinitely.

The realignment of U.S. and other international donors' investments in Afghanistan in fact provides an opportunity to reduce the distortions in Afghanistan's internal politics by increasing the need for compromise on the part of those seeking to maintain power. Ultimately, Afghans themselves will need to establish a more sustainable political system.

The United States cannot wholly dictate the exact outcome of internal negotiations over the balance of power in its future sovereign Afghan partner. But as the principal sponsor of the Afghan government, the United States possesses levers of influence to encourage movement on these two tracks of political reform and reconciliation, through clear expectations and a set of positive and negative inducements. Further, as the most powerful actor in the Afghan conflict with an interest in regional and global stability, the United States also has the responsibility to do so.

\section{Recommendations for reducing the U.S. military footprint and synchronizing military transition with political efforts}

\section{Synchronize military operations with the pursuit of political objectives} and strategy

The realignment and reduction in U.S. military and financial investments in Afghanistan remains the right path for both broader U.S. strategic interests and for the conflict in Afghanistan, particularly as large-scale military intervention shows diminishing returns and as the political and diplomatic processes increase in importance. The principal goal for our military operations must be to support political settlement processes that contribute to the country's stability.

As the United States reduces its military footprint in Afghanistan and shifts to a more limited training, advisory, and support role, the International Security Assistance Force military coalition must also work closely with American and Afghan negotiators to support any negotiated confidence-building measurestemporary ceasefires, the removal of commanders from target lists, or prisoner 
exchanges-with insurgent groups that can contribute to a more sustainable peace process. There are in fact recent reports that such efforts are already underway, with targeted detainee releases intended to broker cooperation with insurgent factions, although their linkage to broader reconciliation talks is unclear. ${ }^{28}$

\section{Condition security assistance on baseline conditions related to political reforms}

The Strategic Partnership Agreement reached with Afghanistan provides an opportunity for long-term engagement in support of Afghanistan. The U.S. interest in the maintenance of Afghan and regional stability means it should be willing to continue to offer limited training and assistance to the Afghan government through and beyond the military transition. While most U.S. troops should be removed from Afghanistan through the remainder of this year and 2013, a residual force can also assist the Afghan government in providing security and logistics for the 2014 elections process, in addition to supporting the gradual demobilization of the Afghan national security forces from their estimated 2014 to 2015 peak.

But these commitments to the Afghan government must be reciprocal. The recent Strategic Partnership Agreement outlined a number of commitments made by the Afghan government toward improving governance. The upcoming NATO conference in Chicago, the international donors' conference at Tokyo, and the negotiation of a more detailed U.S.-Afghan Status of Forces Agreement will be critical for establishing the exact terms under which the Afghan government will make its own commitments, as a responsible steward of international assistance.

Past donor efforts to push the Afghan government to take action by tying conditions to aid have in fact been partially effective, as witnessed in the government's grudging response to the Kabul Bank crisis in 2011 after the International Monetary Fund and other donors suspended on-budget assistance. ${ }^{29}$ But the effectiveness of these mechanisms has been blunted in part by a lack of clear communication about mutual expectations, along with an inconsistent application of incentives and disincentives for good governance and inclusivity.

That's why, in future discussions on both the military and nonmilitary aspects of the relationship, the United States and other international donors must convey the clear reform baselines for their continued support of the Afghan government. They should also affirm a willingness to partner with the Afghan government when it takes the right steps toward a more sustainable political consensus. 


\section{Conclusion}

The NATO conference in Chicago offers member countries an opportunity to plan out their strategy for transitioning security responsibility to Afghans over the next two years. But implementing that strategy in a way that does not exacerbate instability in Afghanistan and the region over the medium and long terms requires expanding the conversation beyond troop withdrawals, areas to be transferred to the Afghan National Security Forces, and the funding for that security force. Discussions on the nature of the Afghan government and the expectations for its continued support by international donors cannot be artificially separated and delayed until subsequent conferences in Tokyo and beyond. There must be recognition by all involved that a security transition is inextricably linked to the political one, and vice versa.

Having signaled support for a political settlement in the strategic partnership agreement, it's now up to U.S., Afghan, and other international officials to understake serious preparations for the Afghan presidential elections in 2014, to facilitate an inclusive Afghan negotiations process linked to regional agreements, and to clarify expectations for the Afghan government through a set of conditions and incentives tied to Afghan government performance.

A transition to Afghan ownership and the drawdown of foreign forces is the right approach for the long-term interests of Afghanistan, the region, and the United States and its NATO partners. But much more work needs to be done to prioritize and carry out the steps necessary for a durable resolution to the political issues at the core of the conflict. 
Caroline Wadhams is a Senior Fellow at the Center for American Progress. She focuses on Afghanistan, Pakistan, terrorism issues, and U.S. national security. Prior to joining CAP, she served as a legislative assistant on foreign policy issues for Sen. Russ Feingold (D-WI). Wadhams also worked at the Council on Foreign Relations in Washington, D.C., as an assistant director and in New York as a research associate on national security issues. Her overseas experience includes work with the International Rescue Committee in Sierra Leone and two years in Ecuador and Chile. She served as a U.S. election observer in Afghanistan's parliamentary elections in September 2010 and in Pakistan's parliamentary elections in February 2008. She was a 2005 Manfred Wörner Fellow with the German Marshall Fund and a term member at the Council on Foreign Relations.

Wadhams received a master's degree in international relations from the Fletcher School of Law and Diplomacy at Tufts University. She has been a guest analyst with numerous international, national, and local news outlets.

Colin Cookman is a Policy Analyst for the National Security and International Policy team at the Center for American Progress. His research and writing at CAP focuses primarily on issues related to Pakistan, Afghanistan, and American policy toward the region. He served as a member of Democracy International's election observation team in Kabul during the 2010 Afghan parliamentary elections. Prior to joining CAP in January 2008, he was an assistant language teacher in Karatsu City, Japan, and an assistant advisor with Habitat for Humanity International's Summer Youth Blitz Program.

Cookman graduated from Boston University magna cum laude with a bachelor's degree in international relations in 2005 and is pursuing a master's degree in international relations with a concentration in South Asia at the Johns Hopkins School of Advanced International Studies.

Brian Katulis is a Senior Fellow at the Center for American Progress, where his work focuses on U.S. national security policy in the Middle East and South Asia. Katulis has served as a consultant to numerous U.S. government agencies, private corporations, and nongovernmental organizations on projects in more than two-dozen countries, including Iraq, Pakistan, Afghanistan, Yemen, Egypt, and Colombia. He was a Fulbright scholar from 1994 to 1995 in Amman, Jordan, where he conducted research on the peace treaty between Israel and Jordan. From 1995 
to 1998 he lived and worked in the West Bank and Gaza Strip and Egypt for the National Democratic Institute for International Affairs. Katulis has published articles in several newspapers and journals, including The Washington Post, Los Angeles Times, Boston Globe, Baltimore Sun, and Middle East Policy, among other publications. He is co-author of The Prosperity Agenda, a book on U.S. national security.

Katulis received a master's degree from Princeton University's Woodrow Wilson School for Public and International Affairs and a bachelor's degree in history and Arab and Islamic Studies from Villanova University.

\section{Acknowledgments}

We are grateful for the input and advice of our colleagues here at the Center for American Progress who have supported the development of this paper and our body of work on Afghanistan to date, particularly John Podesta, Rudy deLeon, and Peter Juul. Any errors are ours alone. As always, our work would not be possible without the help of the Center's hard-working editorial team, including Dan Wagener, Carl Chancellor, Jan Diehm and Erica Mendez Babcock. 
1 For the text of the strategic partnership agreement, see governments of the United States of America and the Islamic Republic of Afghanistan, Enduring Strategic Partnership Agreement (White House, 2012), available at http://www.whitehouse.gov/sites/default/ files/2012.06.01 u.s.-afghanistanspasignedtext.pdf.

2 U.S. Department of Defense, Report on Progress Toward Security and Stability in Afghanistan (2011), page 70, available at http://www. defense.gov/pubs/pdfs/Report_Final_SecDef_04_27_12.pdf.

3 Ann Flaherty, "Feinstein, Rogers Say Taliban 'Stronger' Since Surge," Washington Post, May 6, 2012, available at http://www.washingtonpost.com/world/national-security/feinstein-rogers-say-talibanstronger-since-surge/2012/05/06/glQALbQh6T_print.html.

4 Congressional and Pentagon investigations have particularly focused corruption associated with U.S. military logistics contractsas much as $\$ 360$ million of an overall $\$ 2.16$ million Host Nation Trucking Contract was found to have been diverted to "malign actors", See Karen DeYoung, "U.S. Trucking Funds Reach Taliban, Military-Led Investigation Concludes," Washington Post, July 24, 2011, available at http://www.washingtonpost.com/world/nationalsecurity/us-trucking-funds-reach-taliban-military-led-investigationconcludes/2011/07/22/gIQAmMDUXI_print.html; John F. Tierney, "Warlord, Inc.: Extortion and Corruption Along the U.S. Supply Chain in Afghanistan," Report of the Majority Staff of the House Oversight Subcommittee on National Security and Foreign Affairs, June 2010 available at http://media.washingtonpost.com/wp-srv/world/documents/warlords.pdf.

5 Department of Defense, Report on Progress Toward Security and Stability in Afghanistan, page 51-52.

6 Office of the President of Afghanistan, "Announcement by President Hamid Karzai on the Official Launch of Transition Tranche 3," May 13 2012, available at president.gov.af/en/news/9553

7 For further discussion of the Afghan government, see Colin Cookman and Caroline Wadhams, "Governance in Afghanistan: Looking Ahead to What We Leave Behind" (Washington: Center for American Progress, 2010), available at http://www.americanprogress.org/ issues/2010/05/afghan_governance.html.

8 Karzai's requests for a written agreement on funding levels in the U.S.-Afghan Strategic Partnership Agreement were rejected by Secretary of Defense Leon Panetta. See Elisabeth Bumiller, "U.S. and NATO Finalize Pacts on Ending Afghan War," New York Times, April 18 2012, available at http://www.nytimes.com/2012/04/19/world/asia/ united-states-and-nato-allies-near-deal-on-afghan-aid.html.

9 Department of Defense, Report on Progress Toward Security and Stability in Afghanistan, pages 40-42. Additionally, 39 out of 435 Afghan police units (including Border Police and Civil Order Police) were judged to be "independent with advisors."

10 As of May 1, 2012, there have been 13 reported attacks by Afghan security force members on U.S. forces, resulting in 19 fatalities and an undisclosed number of wounded. Twenty-one attacks killed 35 coalition service members in 2011, including a high-profile attack on advisors working at the Afghan Ministry of Interior. ISAF does not generally report details on incidents in which ISAF soldiers are fatally wounded. See Robert Burns, "U.S. Keeps Mum on Some Afghan Attacks," Associated Press, May 1, 2012, available at http://www.ajc. com/news/nation-world/ap-exclusive-us-keeps-1428944.html.

11 According to ISAF assessments, "southern Pashtuns" comprise only 6.6 percent of Afghan National Army enlisted recruits in the October 2011 to March 2012 reporting period, and Tajiks are "overrepresented" in the Afghan National Police. See Department of Defense, Report on Progress Toward Security and Stability in Afghanistan, pages 20 and 30.
12 "No Afghan Forces Drawdown Until Insurgent Havens Destroyed: MOD," TOLO News, May 9, 2012, available at http://tolonews.com/ en/afghanistan/6172-no-afghan-forces-drawdown-until-insurgenthavens-destroyed-mod-. As of this writing, NATO officials have yet to formally endorse a funding plan, and the exact timing for a reduction in Afghan forces remains unclear. See Donna Cassata, "Allen Wants 'Significant Combat Power' in 2013," Associated Press, March 22, 2012, available at http://www.armytimes.com/news/2012/03/ap afghanistan-john-allen-wants-significant-combat-power-032212/; Thom Shanker and Alissa Rubin, "Afghan Forces Will Be Cut After Taking Leading Role," New York Times, April 10, 2012, available at http://www.nytimes.com/2012/04/11/world/asia/afghan-force-willbe-cut-as-nato-ends-mission-in-2014.html.

13 World Bank, "Transition in Afghanistan: Looking Beyond 2014" (2011), pages 9-10, available at http://siteresources.worldbank.org/ INTAFGHANISTAN/Resources/AFBeyond2014.pdf.

14 Despite efforts to resume bilateral ties, mutual mistrust continues, and NATO supply routes through the country remain closed following the death of 24 Pakistani soldiers in a clash with a joint U.S.-Afghan unit along the border in November 2011. See Declan Walsh, Eric Schmitt, and Steven Lee Meyers, "United States Talks Fail as Pakistanis Seek Apology," New York Times, April 27, 2012, available at http://www.nytimes.com/2012/04/28/world/asia/talks-betweenus-and-pakistan-fail-over-airstrike-apology.html?pagewanted=print

15 “Pakistan, Afghanistan, US Consider Safe Passage for Taliban Militants," Reuters, April 27, 2012, available at http://dawn. com/2012/04/27/pakistan-afghanistan-us-consider-safe-passagefor-taliban-militants/. The Taliban's subsequent denunciation of this offer emphasizes the senior leadership's sensitivity to moves that might split its control over field commanders. See Tahir Khan, "Afghan Peace Process: Taliban Spurn 'Safe Passage' Offer," Express Tribune, April 29, 2012, available at http://tribune.com.pk/story/371585/afghan-peace-process-taliban-spurn-safe-passage-offer/.

16 Secretary of State Hilary Clinton, "Remarks at the Launch of the Asia Society's Series of Richard H. Holbrooke Memorial Adresses," February 18, 2011, available at http://www.state.gov/secretary/ $\mathrm{rm} / 2011 / 02 / 156815 . \mathrm{htm}$.

17 Membership in these groups appears to be fluid, and most leaders appear to maintain their own separate parties within the larger coalition. Some major groups include the National Front of Afghanistan led by former First Vice President Ahmad Zia Massoud; the National Coalition of Afghanistan led by former foreign minister Abdullah Abdullah; and the Truth and Justice Party, whose members include former Interior Minister Hanif Atmar and Afghanistan Independent Human Rights Commission chairwoman Sima Samar.

18 For a brief overview of the inception and resolution of the 2010 parliamentary election crisis, see Jed Ober, "Karzai's Court," AfPak Channel, July 7, 2011, available at http://afpak.foreignpolicy.com/ posts/2011/07/07/karzais court; Scott Worden, "Karzai Blinks in Afghan Election Crisis," AfPak Channel, August 10, 2011, available at http://afpak.foreignpolicy.com/posts/2011/08/10/karzai_blinks_in_ afghan_election_crisis.

19 The IEC has proposed changes to the electoral law that would reiterate its role as the sole decision making body on electoral complaints and would give commissioners the power to elect the organization's chairman. The draft law does not appear to offer parliament a role in confirming commission members, however, who will continue to be presidentially appointed. See Qayoom Suroush, "Ahmadzai: Changes to the Electoral System Demand Political Support," Bamdad, March 31, 2012, available at http://www.bamdad.af/english/story/1691.

20 For the most recent rejection of talks with the Afghan government, see Tahir Khan, "Afghan Peace Process: Taliban Spurn 'Safe Passage' Offer," Express Tribune, April 29, 2012, available at http://tribune.com. $\mathrm{pk} /$ story/371585/afghan-peace-process-taliban-spurn-safe-passageoffer/. 
21 See, for example, recent comments by Interior Minister Bismillah Mohammadi and Afghan National Front leader Ahmad Zia Massoud, among others. "Afghan Government Says Taliban Process 'On Track', Radio Free Europe/Radio Liberty, April 30, 2012, available at http:// www.rferl.org/content/afghan_government_says_taliban_process on track/24564100.html; "Government Has No Political Commitment to Fight Terrorism: National Front," TOLO News, April 28, 2012, available at http://tolonews.com/en/afghanistan/6046-governmenthas-no-political-commitment-to-fight-terrorism-national-front.

22 "Murdered Afghan Talks Head Rabbani Replaced by Son," BBC News, April 14, 2012, available at http://www.bbc.co.uk/news/world-southasia-17712058.

23 International Crisis Group, "Talking About Talks: Toward a Political Settlement in Afghanistan" (2012), pages 19-22, available at http://www.crisisgroup.org/ /media/Files/asia/south-asia/ afghanistan/221-talking-about-talks-toward-a-political-settlementin-afghanistan.pdf; Deedee Derksen, "Impact or Illusion? Reintegration Under the Afghanistan Peace and Reintegration Program" (Washington: U.S. Institute of Peace, 2011), available at http://www. usip.org/publications/impact-or-illusion-reintegration-under-theafghanistan-peace-and-reintegration-program.

24 Huma Imtiaz, "Pakistan Cannot Make Crucial Decisions Based on One Phone Call," Express Tribune, February 16, 2012, available at http://tribune.com.pk/story/337241/pakistan-cannot-make-crucialdecisions-based-on-one-phone-call-sherry-rehman/.

25 "Afghan Taliban Suspend Peace Talks with U.S.," Al Jazeera English, March 16, 2012, available at http://www.usip.org/publications/theafghan-peace-process-transition-and-the-do-list-the-us.
26 Gordon Lubold, "The Afghan Peace Process, Transition, and the To-Do List for the U.S." (Washington: U.S. Institute of Peace, 2012), available at http://www.usip.org/publications/the-afghan-peaceprocess-transition-and-the-do-list-the-us.

27 Sami Yousafzai and Ron Moreau, "How Afghan Peace Talks Are Splintering the Taliban," Daily Beast, February 13, 2012, available at http://www.thedailybeast.com/newsweek/2012/02/12/how-afghanpeace-talks-are-splintering-the-taliban.print.html.

28 Kevin Sieff, "Secret U.S. Program Releases High-Level Insurgents in Exchange for Pledges of Peace," Washington Post, May 6, 2012, available at http://www.washingtonpost.com/world/asia_pacific/ secret-us-program-releases-high-level-insurgents-in-exchange-forpledges-of-peace/2012/05/06/gIQAFfJn6T_print.html.

29 The aftermath of the Kabul Bank crisis and the Afghan government's response to it is still ongoing, but the linkage of IMF loan agreements - and, by association, contributions from many other Afghan donors-has clearly forced the Afghan government to devote more attention to, at minimum, being seen as taking action to resolve the crisis. See Colin Cookman, "Getting Afghanistan's House in Order" (Washington: Center for American Progress, 2011), available at http://www.americanprogress.org/issues/2011/03/afghanistans_house_in_order.html; Lesley Wroughton and Jan Harvey, "IMF Renews Afghan Ties, Approves Loan Deal," Reuters, November 16, 2011, available at http://in reuters.com/article/2011/11/15/ idINIndia-60542820111115?feedType=RSS\&feedName=southAsiaNe ws; Emma Graham-Harrison, "Kabul Bank Scandal: Hamid Karzai Sets Up Special Tribunal," The Guardian, April 4, 2012, available at http:// www.guardian.co.uk/world/2012/apr/04/kabul-bank-hamid-karzaispecial-tribunal. 
The Center for American Progress is a nonpartisan research and educational institute dedicated to promoting a strong, just, and free America that ensures opportunity for all. We believe that Americans are bound together by a common commitment to these values and we aspire to ensure that our national policies reflect these values. We work to find progressive and pragmatic solutions to significant domestic and international problems and develop policy proposals that foster a government that is "of the people, by the people, and for the people."

Center for American Progress 